\title{
CSR and Sales Performance: Examining Mediating and Moderating Processes: An Abstract
}

\author{
Sandra Castro-González, Belén Bande, and Fernando Losada Pérez
}

\begin{abstract}
Performance is especially relevant among sales staff. However, knowledge of the variables that encourage salespeople's performance is still limited.

The purpose of this paper is to contribute to partially fill this gap by analyzing the relationship between corporate social responsibility (CSR), salespeople's organizational commitment, organizational pride, and salespeople's performance. This study's empirical analysis is based on the information provided by 176 supervisor-salesperson dyads from 96 companies. Structural equation modeling was used to analyze the psychometric proprieties of the measurement scales and to test the proposed direct hypotheses, while conditional process analysis was used to test the proposed mediation and moderation hypothesis. The results confirm that CSR perception is positively related to the salespeople's performance indirectly, through organizational pride and commitment. Furthermore, the findings show that the relation between organizational pride and commitment improves when there is a responsible leader on the organization. In addition, the paper identifies the main implications of these results for the management, and it makes some suggestions for future studies.
\end{abstract}

References Available Upon Request

Acknowledgment This publication has been funded with support from the Galician Plan for Research, Innovation, and Growth (Plan I2C) of the Xunta de Galicia (Consellería de Cultura, Educación y Ordenación Universitaria).

\footnotetext{
S. Castro-González $(\bowtie) \cdot$ F. L. Pérez

University of Santiago de Compostela, Galicia, Spain

e-mail: sandra.castro@usc.es; fernando.losada@usc.es

B. Bande

University of Navarra, Navarra, Spain

e-mail: bbande@unav.es
} 